\title{
Kilka uwag o polskim socjolekcie przestępczym z okresu XVIII w. (glosa do informacji z „Gazety Warszawskiej” z 1778 r.)
}

\author{
A few remarks about Polish criminal jargon from the 18th century \\ (a gloss to a press release from of "Gazeta Warszawska" from 1778) \\ Jarosław PACUŁA ${ }^{1}$ \\ Uniwersytet Śląski w Katowicach
}

\begin{abstract}
The subject of the article is the vocabulary of Polish criminals from the 18th century. The author reached for a press release from 1778. This press release is one of the oldest credentials of the Polish criminal jargon. The text describes a court hearing and only mentions the existence of specific communication style between villains that the court had to face. The news from "Gazeta Warszawska" contains eighteen lexemes. The author of this article discusses these words - he indicates the etymology of these jargonisms and presents a continued existence of the vocabulary in Polish (in the 19th and 20th centuries). Some remarks on the provenance of jargon terms may raise doubts among readers. The author is aware of this. However, he considers it significant to bend over the form and semantics of the accumulated vocabulary researchers often refer to this press release from the 18th century, but do not focus on the history of the vocabulary of Polish criminals.

Keywords: history of the Polish criminal sociolect, 18th-20th century, lexical semantics, diachronic linguistics
\end{abstract}

1 https://orcid.org/0000-0002-9972-7925

Uniwersytet Śląski w Katowicach, Instytut Językoznawstwa

jaroslaw.pacula@us.edu.pl 


\section{Streszczenie}

Tematem artykułu jest słownictwo polskich przestępców z XVIII wieku. Autor sięga do wiadomości prasowej z 1778 roku. Ta notka prasowa należy do najstarszych poświadczeń polskiego żargonu kryminalnego. Tekst informuje o procesie sądowym, a tylko na marginesie zaznacza istnienie specyficznej komunikacji złoczyńców, z którą musiał się zmierzyć sąd. Wiadomość z „Gazety Warszawskiej” zawiera aż osiemnaście leksemów. Słowa te omawia autor niniejszego artykułu - wskazuje etymologię żargonizmów oraz przedstawia dalsze życie słownictwa w języku polskim (w XIX i XX wieku). Kilka uwag dotyczących proweniencji określeń socjolektalnych może budzić wątpliwości czytelników, z czego autor zdaje sobie sprawę. Za celowe uznaje jednak pochylenie się nad kształtem i semantyką zgromadzonego słownictwa, bo chociaż różni badacze często powołują się na artykuł prasowy z XVIII wieku, to niewiele uwagi poświęcają historii występującego w nim słownictwa polskich przestępców.

Słowa kluczowe: historia polskiego socjolektu przestępczego, XVIII w.-XX w., semantyka leksykalna, językoznawstwo diachroniczne

\section{Wprowadzenie}

Na temat polskiego socjolektu przestępczego powstało już sporo prac, przy czym $\mathrm{z}$ reguły ich autorzy bazują na materiale XX-wiecznym, względnie historycznym, acz poświadczonym w XIX i XX wieku². I chociaż potwierdzenie istnienia specyficznego języka złoczyńców można dostrzec już w szesnastym stuleciu, często nie przykłada się większej uwagi do wzmianek prasowych i literackich sprzed XIX wieku. Niewątpliwie do takich dokumentacyjnych tekstów należy wiadomość prasowa zamieszczona w „Gazecie Warszawskiej” z 30 grudnia 1778 r., do której - co prawda - niekiedy nawiązują opracowania językoznawcze, ale bez pogłębionej refleksji na temat etymologii i „życia” wymienionych tam słów ${ }^{3}$. Tymczasem bliższy ogląd tej leksyki może przynieść

\footnotetext{
2 Do tych prac należą m.in.: Ułaszyn, 1951; Królikowska, 1975, s. 55-77; Milewski, 1971, s. 91-101; Pacuła, 2019a, s. 245-258; Pacuła, 2019b, s. 363-379; Małocha, 1994, s. 135-170.

3 Henryk Ułaszyn, opisując źródła do badania historii języka przestępców, odnosi się do wzmianki prasowej z „Gazety Warszawskiej”, pisząc: „Pomijając krótką notatkę w «Gazecie Warszawskiej» z roku 1778 [...], a zawierającą zaledwie kilkanaście wyrazów złodziejskich, powieść Rusieckiego uważać należy za najdawniejszy drukowany zabytek (1844) piśmiennictwa naszego zawierający wyrazy złodziejskie, których znaczna część do dziś jest w użyciu. Wprawdzie spotykamy się z gwarą złodziejską już w rękopisie z r. 1580, a następnie w książce drukowanej w r. 1604 («Scylurus» Jana Jurkowskiego), ale gwary te nie łączą się pod względem leksykalnym z obecnie na ziemiach polskich używanemi gwarami złodziejskiemi. Jako zjawiska odosobnione, stoją na uboczu" (Ułaszyn, 1913, s. 272). Więcej o przyczynkach do badań dawnego języka polskich przestępców w: Stępniak, 1972, s. 263-279.
} 
ciekawe wnioski na temat historii języka polskich kryminalistów i dopełnić istniejące już opracowania $\mathrm{z}$ tego zakresu.

We wspomnianej informacji prasowej czytamy:

W przefzłym tygodniu, naftąpiła Exekucya z Dekretu Sądow Marfzałkowfkich Kor: Ultimar Inftantice nieiakiego Tomafza Kowalfkiego rodem z Niepołomic, który za wielokrotne kradzieże, śmiercią Szubienicy ukarany zoftał, inni zaś Complices $\mathrm{w}$ iego wfpółeczeńftwie będący, więzieniem na wiele lat, y robot publicznych fą fsądzeni. Z Indygacyi zaś tychże Kryminaliftow, Sąd uwiadomiony zoftał, iż dla utainienia fwych zamyfłow, uformowali ięzyk iedynie fobie zrozumiany, który dla wiadomości każdego podaiefię, Pieniądze, nazywali Łakomce, Czerwone Złote Opaleńce, Kiefzeń Dolina, Ręka Sięgawka albo też Grabki, Moneta biała Rudniki, Rufony, Bielizna, Pajęczyna, Chuftka Filucha, Pałka Szumowifko, Głowa Makówka, Nogi Ligary, Wół Rogi, Stróż Chmura, Chleb Sumer. Gdy który z nich powiedział, buchnąt, znaczyło że ukradł; gdy powiedział zaiął, znaczyło że uderzył; y tam daley. A gdy powiedziano Buchnoł Łakomce z Doliny, znaczyło, ukradł pieniądze z kiefzeni. Gdy powiedziano: Zaiął Szumowifkiem po ligarach, albo po Makówce, znaczyło, że uderzył pałką po nogach, albo po głowie. Gdy rzeczono: Zmiótł Paięczynę, znaczyło, ukradł bieliznę, y tam daley. („Gazeta Warszawska” 1778, nr 104, s. 1-2)

Do artykułu nawiązuje Karol Estreicher w 1859 r. w Języku złoczyńców zamieszczonym na łamach „Rozmaitości” (dodatku do „Gazety Lwowskiej”), pisząc:

Gazeta podaje tylko próbkę języka, zaledwie wyrazów kilkanaście; niewątpliwie był on obfitszy; a lubo podaje, że ci złoczyńcy uformowali sobie nowy język, przypuścić raczej wypada, że już istniejący język łotrowski przyjęli od poprzedników swoich I tylko może ubogacili go, lub zastosowali zręczniej w praktyce łotrowskiej. (JZESTR(A), S. 89)

Z dalszego komentarza Estreichera wybrzmiewa przekonanie, że język przestępców należy postrzegać jako język plugawy, którym nie warto i - co więcej - nie wypada się zajmować dokładniej:

W Niemczech, w Anglii i we Francyi gdzie filuterya przemysłowców podobnych doszła wysokiego stopnia cywilizacyi ujemnej, okazało się potrzebnem studyowanie nie tylko zwyczajów i obyczajów filutów, ale i ich potocznej mowy, która w ich uściech, dla nieświadomych języka stawała się częstokroć kotwicą wybawienia od kary, a służyła za wyborny środek porozumiewania się na wszystkich kończynach kraju. 
[...] U nas chwała Bogu, cywilizacya w tym względzie opóźniła się, więc potrzeby nie ma podobnych dziełek [wyjaśniających język przestępców - J.P.], dla tego też i wyrazownictwo złoczyńców tuła się tylko po powieściowych obrazkach nie będąc przedmiotem poważniejszego śledzenia. To też ani Linde, ani Ropelewski, ani Mrongowiusz lub Trojański nie wcielili do swoich słowników tego, co służy za hieroglif wyrzutkom społeczeństwa. (JZESTR(A), S. 90)

Łagodniejszy w ocenie języka złoczyńców był Karol Appel, językoznawca z przełomu XIX I XX w.:

Mówiąc o języku wydziedziczonych klas społeczeństwa, dotykam bolesnej dziś rany bandytyzmu: chodzi mi bowiem o mowę tajemną złoczyńców, o t. zw. u Francuzów Argot [...]. Od „zawodowców” (smutny niestety zawód!), argot przechodzi zwykle do języka dziadów-źebraków, do jęz. andrusów i łobuzeryi ulicznej, kobiet upadłych. Na języku tych sfer wzorują się następnie, z pobudek humorystycznych, inne klasy społeczne i t. d. i oto wyrastają, jak grzyby po deszczu nowe rodzaje, argot czyli gwary burszów-studentów, młodych adeptów sztuki, uczni szkół i rzemiosł i nawet, o zgrozo, naszych panienek!

[...] I rzeczywiście badanie powstania, wytworzenia się wpośród społeczeństwa takich sztucznych gwar zw. argot jest niezmiernie ciekawem i pouczającem, zarówno dla lingwisty, jak i socyologa. (Appel, 1908, s. 28-29)

Materiał leksykalny poddany obserwacji liczy osiemnaście jednostek, z czego trzy to czasowniki (buchnąć, zająć, zmieśc), pozostałe to rzeczowniki (chmura, dolina, filucha, grabki, ligary, łakomce, makówka, opaleniec, pajęczyna, rogi, rudnik, ruson, sięgawka, sumer, szumowisko). Wszystkie słowa opatrzono komentarzem filologicznym dotyczącym ich proweniencji oraz obecności na gruncie polskiego socjolektu w XIX i XX w. (w tym ewentualnych zmian semantycznych bądź „zgonu” leksemu w późniejszym okresie). Pomocne w ustaleniu statusu poszczególnych słów stały się opracowania dokumentujące stan słownictwa socjolektalnego w okresie od połowy XIX w. do początkowych dekad następnego stulecia. Tekstami tymi są: Karola Estreichera Język złoczyńców z 1859 r. [dalej JzESTR] i Gwara złoczyńców z 1867 r. [GzESTR], Henryka Felsztyńskiego Wiadomość o języku bosańskim w Galicyi z około 1861 r. [JBFEL], Seweryna Udzieli Żargon złodziejski we Lwowie z 1892 r. [ŻzUDZ], Antoniego Kurki Słownik mowy złodziejskiej z 1899 r. [SMZKUR], opracowanie Juliana Jaworskiego Kumać po lembersku z 1901 r. [KPLJAW], Karola Estreichera Szwargot więzienny z 1903 r. [SZWESTR], Jana Łosia 
Słowniczek gwary więziennej z 1913 r. [SGWŁoŚ] ${ }^{4}$ oraz wydany w 1922 r. Żargon mowy przestępców Wiktora Ludwikowskiego i Henryka Walczaka [ŻMPLUDWA]. Pozyskane z nich dane skonfrontowano z notacjami obecnymi w opracowaniach poświęconych językowi przestępczemu po drugiej wojnie światowej. Dodatkowo - z uwagi na fakt, że słownictwo socjolektalne często przenika do języka potocznego - zweryfikowano jego obecność w historycznych i współczesnych słownikach ogólnych, wychwytując w ten sposób moment owego przeniknięcia. Niekiedy też $\mathrm{w}$ celu pełnego zobrazowania „życia” jakiejś jednostki leksykalnej zaznaczono jej interżargonowy $\mathrm{y}^{5} \mathrm{i}$ internacjonalny $\mathrm{y}^{6}$ charakter.

\section{Analiza}

Prezentację zgromadzonego materiału zacznijmy od czasowników; są to: buchnąć 'ukraść', zająć 'uderzyć' i zmieść 'ukraść'.

Jeśli chodzi o pierwszy z nich, to ma on długi żywot, w tym samym sensie notują go późniejsze - XIX- i XX-wieczne - opracowania poświęcone socjolektowi środowisk przestępczych: JZESTR(B), GZESTR, ŻzUDZ, SMZKUR, SzWESTR, SMZLUDWA, także w formie niedokonanej buchać. Wprawdzie wiadomość prasowa, z której zaczerpnięto materiał, nie podaje form pokrewnych do buchnąć czy buchać, jednak potencjalnie mogły one istnieć, wszak już w opracowaniach o kilkadziesiąt lat późniejszych można się zetknąć z: określeniami kradzieży - buchawka 'kradzież' GzESTR, SzWESTR, SMZLUDWA i buchanka 'kradzież' JzESTR(A), GzESTR, SzWESTR, SMZLUDWA; nazwami złodzieja - buchacz 'złodziej' JZESTR(A), GzESTR, ŻzUDZ, SMZKUR, SZWESTR, SMZLUDWA i buchaczka 'złodziejka' SMZLUDWA, często także w postaci wyrażeń z elementem dookreślającym - buchaczl andrus pająkowy 'złodziej odrzynający tłomoki z powozów' GzEsTR, SzWESTR/ buchacz pająkowy'złodziej bielizny ze strychu' SMzLUDWA, buchaczl andrus od potoku 'złodziej, co kradnie z wozów' GzESTR, SzWESTR/ buchacz potokowy 'złodziej kradnący z wozów i platform' SMzLUDWA, buchacz/ andrus zza parkanu 'złodziej kieszonkowy' GZESTR, SZWESTR, buchaczl andrus z doliny 'złodziej

\footnotetext{
${ }^{4}$ Jan Łoś sporządził wykaz słów wydobytych z powieści Gustawa Daniłowskiego Wrażenia więzienne, wydanej w $1908 \mathrm{r}$.

${ }^{5}$ Szerzej na ten temat w: Grabias, 1994, s. 242-243; zob. np.: Witkowski, 1992, s. 271-273; Zgółkowa, 1994, s. 41-47.

${ }^{6}$ Zapożyczanie między socjolektami należącymi do różnych języków etnicznych jest zjawiskiem dość częstym; zob. Ułaszyn, 1951, s. 56-57.
} 
kieszonkowy' GzESTR, SzWESTR/ buchacz dolinowy 'złodziej kieszonkowy' SMZLUDWA, buchacz bojdekowy/ wichrowy 'złodziej strychowy' SMZLUDWA, buchacz skokowy 'złodziej mieszkaniowy w nieobecności lokatora' SMZLUDWA, buchacz szabrowy 'włamywacz' SMZLudWA. Samo buchnąć na gruncie języka kryminalistów jest neosemantyzmem powstałym w wyniku zawężenia znaczenia, związanym ze zrobieniem czegoś w sposób dynamiczny, nagły, niespodziewany: buchnąć 'rozprzestrzenić się, wydobyć się w sposób gwałtowny' (SXVII/XVIII, SL, SWIL, SW, SDOR, USJP, WSJP) $\leftarrow$ pot. 'wykonać nagły ruch, rzucić (się), uderzyć' (SXVII/XVIII, SL, SWIL, SW, SDOR, UsJP, WSJP $) \leftarrow$ 'ukraść. Słowo buchnąć w znaczeniu 'ukraść' zaadaptowało się w polszczyźnie ogólnej - jako potocyzm wywodzący się z języka złodziejskiego notowane jest w SW, potem podają je także SDOR, SPLP, USJP, SPP, WSJP. Jako wyraz należący do XIX-wiecznej mowy półświatka zalicza go SGWWIECZ, a na jego funkcjonowanie w drugiej połowie XX w. wskazują notacje w JZŁUŁASZ, STGPSTĘP, SAKAN.

Wyraźnie krótszy żywot i zupełny brak oddziaływania na polszczyznę ogólną dotyczy czasowników: zająć i zmieść - oba po raz ostatni jako słowa charakterystyczne dla mowy przestępczej pojawiają się w opracowaniu z 1903 r.: zająć w znaczeniu 'uderzyć' notują JZESTR(C) i SzWESTR, z kolei zmieść w sensie 'ukraść' przywołują JzESTR(C), GZESTR i SzWESTR, nie podaje ich już jednak ani SGWŁoś, ani SMZLUDWA. Oba określenia mają charakter żartobliwy, przy czym w przypadku zająć $\mathrm{w}$ zasadzie przesunięcie semantyczne jest niewielkie, zakres znaczeniowy wyrazu na gruncie socjolektu niemal całkowicie pokrywa się z zakresem słowa funkcjonującym w języku ogólnym: otóż zająć to 'chwytać, zagrabiać, zabierać, wziąć coś $\mathrm{w}$ posiadanie' (SXVII/XVII, SL, SWIL, SW, SDOR, USJP, WSJP), tyle tylko, że w języku przestępczym w grę wchodzi branie czegoś bez pozwolenia, bez czyjejś wiedzy, w tajemnicy; natomiast znaczenie czasownika zmieść, prymarnie: 'usunąć coś skądś za pomocą miotły, szczotki, zwykle energicznie' (SXVII/XVII, SL, SWIL, SW, SDOR, USJP, WSJP), na gruncie języka przestępczego przyjęło dodatkowy sem - 'bez czyjejś zgody, potajemnie'.

Pozostałe określenia wymienione w wiadomości zamieszczonej w „Gazecie Warszawskiej” to rzeczowniki. Ich omówienie można rozpocząć od jedynego określenia człowieka - chmura 'stróż'. Funkcjonowanie słowa w języku przestępców z XIX wieku i początkowych dekad następnego stulecia poświadczają: JzESTR(A), GzESTR, SzWESTR ('zwierzchnik, każdy dozór mający, bądź wysokiego stopnia bądź nie') i SMZLudWA ('zwierzchnik, dozorca'). $\mathrm{W}$ opracowaniach $\mathrm{z}$ drugiej połowy $\mathrm{XX} \mathrm{w}$. nie znajdziemy potwierdzenia na przetrwanie słowa jako określenia przestępczego. Co się jednak dotyczy jego 
proweniencji, to najprawdopodobniej słowo jako nazwa przełożonego, strażnika jest wynikiem asocjacji - skojarzenia pełnionej funkcji z miejscem znajdowania się chmury jako zjawiska atmosferycznego: „bycia nad”. Jeśli bowiem zwrócimy uwagę na definicję zamieszczoną w GzESTR: 'każdy dozór mający, bądź wysokiego stopnia bądź nie', dostrzeżemy wspomnianą zależność („czuwający nad”, „sprawujący opiekę nad”, „nadzorujący” itd.) Zresztą takiej interpretacji sprzyjają notacje zamieszczone w SW: chmura [zł.] 'zwierzchnik, każdy mający dozór, stróż', czarna chmura 'komisarz policyjny'.

W analizowanym materiale znalazły się aż cztery nazwy części ciała dwa określenia rąk, jedno miano nóg i jedna nazwa głowy. Ich charakterystykę zacznijmy od neosemantyzmów.

Jeśli chodzi o określenie makówka 'głowa', to notują je JZESTR(B), GzESTR, ŻzUDZ, SMzKuR, SzWESTR, SMzLUDWA [tu też w postaci makuwa], przy czym SzWESTR jako jedyne opracowanie podaje także mak 'głowa'. Słowo to $\mathrm{w}$ mowie przestępczej dosyć powszechnie funkcjonuje jeszcze $\mathrm{w}$ drugiej połowie XX w., o czym świadczą notacje w JZŁUŁASZ, STGPSTĘP czy SAKAN. Jeśli chodzi o pochodzenie leksemu w języku przestępczym, to łatwo zauważyć, że jest on neosemantyzmem powstałym $\mathrm{w}$ wyniku przeniesienia znaczenia, a cechą dystynktywną jest tu kształt: makówka 'owoc maku w postaci kulistej torebki nasiennej' (SWIL, SW, SDOR, USJP, WSJP) « 'głowa' (choć SL i SWIL nie odnotowują odrębnego znaczenia, na jego obecność w XVIII i XIX w. wskazują ilustracje umieszczone $\mathrm{w}$ artykułach hasłowych). W tym wtórnym znaczeniu słowo dość wcześnie pojawiło się w polszczyźnie potocznej, do dziś słowniki kwalifikują je przeważnie jako określenie żartobliwe (zob.: SDOR, SplP, UsJP, SPP, WSJP) (Buttler, 1991, s. 42), występuje także w innych socjolektach, np. gwarze młodzieżowej - uczniowskiej (zob. SGUZG) czy studenckiej (zob. Grabias, 2019, s. 160), jak też języku zawodowym policjantów (Karwatowska, Jarosz, 2011, s. 18). Mało prawdopodobne jest jednak to, by $\mathrm{w}$ polszczyźnie potocznej znaczenie pojawiło się w wyniku oddziaływania socjolektu przestępczego; co więcej, wydaje się, że kierunek przepływu był odwrotny (por. makówka 'makowa główka') i to język przestępczy zaadoptował potoczny sens 'głowa' (por. znane od staropolszczyzny wyrażenie główka jak makówka, które zdradza "prostotę” mechanizmu metaforyzacji, ujawniającą się także w tworzeniu dodatkowego sensu leksemu na gruncie socjolektów nie tylko polskich [Хобзей, Сімович, Ястремська, Дидик-Меуш, 2012, s. 433-434]).

Odnosząc się do określeń ręki (rąk), wypada zauważyć, że miano sięgawka, nadal funkcjonujące na przełomie XIX i XX w. (notują je jeszcze JZESTR(B), GzESTR i SzWESTR), w zasadzie przestaje istnieć w mowie 
przestępczej w pierwszych dekadach dwudziestego stulecia - nie przywołuje go już SMZLUDWA z 1922 r., nie podają go także opracowania późniejsze, a GWWIECZ wzmiankuje, że sięgawka to dawne, nieużywane już określenie ręki. Trzeba jednak zaznaczyć, że wprawdzie słowo to - w wyniku zatracenia cechy tajności i w konsekwencji niespełniania funkcji zawodowokomunikacyjnej - przestało funkcjonować w mowie przestępczej, ale zachowało się między innymi w gwarze studenckiej $\mathrm{z}$ lat 70 . XX wieku (Grabias, 1974, s. 28). Jeśli natomiast chodzi o pochodzenie określenia, to łatwo zauważyć, że jest ono derywatem odczasownikowym $(\leftarrow$ sięgać 'wyciągać rękę, by wziąć coś, dotknąć czegoś znajdującego się w pobliżu').

Drugie określenie ręki, które zostało wymienione w notce prasowej z 1778 r., to grabka. Zasadniczo w tej postaci słowa nie notują XIX- i XXwieczne opracowania poświęcone językowi środowisk przestępczych: w JBFEL i KPLJAW sens 'ręce' pojawia się przy formach grabie i graby 'ręce', w SMZKUR, KPLJAW, SzWESTR, SGWŁoŚ, SMzLUdWA znaczenie 'ręka' towarzyszy formie graba; z tego okresu są też ekspresywizmy grabcia - notowane przez SZWESTR, SMZLUDWA (zob. Jaczewski, 1938-1939, s. 180), i grabica - przywołane przez SzWESTR. Wyłącznie GWWIECZ przytacza słowo grabki 'ręce' jako dawne określenie używane przez warszawski proletariat. Niemniej jednak tak liczne warianty nazewnicze, odnoszące się do wspólnego, uogólnionego sensu: 'kończyna uformowana na kształt grabi i niczym grabie umożliwiająca pochwycenie i zagarnięcie czegoś' (por. grabie 'narzędzie służące m.in. do zgarniania liści, słomy, zboża'), pozwalają założyć potencjalne funkcjonowanie w mowie kryminalistów słowa grabka 'ręka' (l. mn. grabki). Jest to tym bardziej prawdopodobne, że historyczne opracowania przytaczają postać grabki (JZESTR(A), GzESTR, ŻzUDZ, SMZLUDWA), choć w nieco innym znaczeniu, jako nazwę części ręki - 'palce'. Wypada przy tym dodać, że w objętych ekscerpcją historycznych opracowaniach występuje liczna grupa wyrazów pokrewnych: określenia kradzieży - grabić 'kraść' SMzKUR, SMZLUDWA, zagrabić 'skraść' SMZKUR, grabina 'rabunek' SMZLUDWA, a także części garderoby związanej z ręką - grabiączka 'rękawiczka' SMzKuR, SMZLudWA. Część z nich występuje i dziś - przede wszystkim w gwarze młodzieżowej, uczniowskiej, studenckiej (zob. np. SGUZG, SAKAN), z kolei niemal każde z przytoczonych słów jako wyrazy znane środowisku kryminalistów $\mathrm{z}$ drugiej połowy $\mathrm{XX}$ w. podają JZUŁASZ, STGPSTĘP, SAKAN. Mało tego, grabal graby jako XIX-wieczne przenośne, potoczne określenie ręki lub dłoni odnotowuje SW, pojawia się ono również w późniejszych słownikach, także ogólnych (zob. SDOR, SPP, USJP, WSJP). Niewątpliwie powstaniu i utrwaleniu wszystkich wspomnianych form $\mathrm{w}$ języku przestępczym oraz ich adaptacji $\mathrm{w}$ różnych odmianach socjalnych 
i funkcjonalnych polszczyzny sprzyjał fakt, że w języku polskim już od XV w. posługiwano się czasownikiem grabić w znaczeniu przenośnym - 'zabierać gwałtem, rabować, zabierać coś komuś siłą', a od następnego stulecia notuje się grabki jako formę deminutywną od grabiel graby 'przyrząd do zgarniania czegoś' (zob.: SSTP, SXVI, SXVII/XVIII, SL, SWIL, SW, SDOR, USJP, WSJP) (Długosz-Kurczabowa, 2005, s. 168).

Niekłopotliwa w ustaleniu proweniencji jest nazwa innej części ciała ligary 'nogi', której funkcjonowanie w języku przestępczym w XIX wieku i początkowych dekadach następnego stulecia poświadczają: JZESTR(A), GzEsTR, SzWEsTR, SMzLUDWA (jako określenie dawniej używane w gwarze warszawskiej słowo wymienia GWWIECZ). Jednak łączenie leksemu z innym, podobnie brzmiącym słowem o tym samym znaczeniu - ogary (zob. np. SzWESTR) wydaje się fałszywym tropem. Owszem, kreatywność językowa przedstawicieli środowisk przestępczych była i jest cechą tych wspólnot komunikatywnych, ale $\mathrm{w}$ przypadku nazwy ligary dopatrywanie się gry słownej (przekształceń formalnych wspartych podobieństwem brzmieniowym z ogary oraz łączenia sensu 'nogi - narząd do poruszania się' ze znaczeniem 'pies myśliwski, gończy') należy odrzucić - ligary w mowie półświatka to neosemantyzm motywowany asocjacjami: nogi zostały skojarzone z belkami, na których umieszcza się coś, filarami utrzymującymi jakąś platformę, a więc właśnie ligarami (dziś legarami).

Jednym z bardziej charakterystycznych słów należących do języka przestępców (pierwotnie używanym tylko przez złodziei) jest rzeczownik dolina 'kieszeń', funkcjonujący także współcześnie; notują go nie tylko historyczne opracowania: JBFEL, JzEsTR(A), GzESTR, SMzKuR, KPLJAW, SZWESTR, SMZLUDWA, ale również teksty poświadczające stan gwar środowisk kryminalnych z drugiej połowy XX w.: JzUŁASZ, STGPSTĘP, SAKAN. Co więcej, wyraz dolina dość wcześnie wyszedł poza środowisko przestępców, a podobnie jak kilka innych wymienionych $\mathrm{w}$ artykule słów - trafiając do polszczyzny potocznej i adaptując się $w$ innych socjolektach, utracił cechę tajności; w znaczeniu 'kieszeń' i jako określenie środowiskowe notują go: SDOR, SPLP, SPP, WSJP, SGUZG. Samo określenie jest neosemantyzmem motywowanym skojarzeniem doliny jako zagłębienia w terenie $\mathrm{z}$ kieszenią jako workowatego elementu różnych części garderoby, tworzącego otwarte zagłębienie, schowek (niewykluczone, że neosemantyzacja dokonała się w tym przypadku pod wpływem języka francuskiego, wszak vallade/ valade prowansalski wariant vallée 'dosłownie: dolina' - to w dawnym, XVIII- i XIXwiecznym francuskim argocie 'kieszen' [Michel, 1856, s. 414; Saint-Hilaire, 
Raban, 1929, s. 337; Zacone et Clémens, 1870, s. 447]). Jeśli jednak przyjrzeć się notacjom $\mathrm{w}$ rodzimych historycznych opracowaniach, można zauważyć, że $\mathrm{w}$ początkowym okresie $\mathrm{XX} \quad \mathrm{w}$. słowo dolina na gruncie socjolektu przestępczego rozszerzyło znaczenie - w SMzLUDWA z 1922 r. odnotowano dodatkowy sens: 'kradzież kieszonkowa' (jako określenie dawniej używane w gwarze warszawskiej wymienia GWWIECZ, w znaczeniu 'kradzież' wyraz podaje też WsJP, opatrując notację kwalifikatorem „warsz. przestęp.”). Na popularność słowa w dawnej mowie złodziejskiej wskazuje liczna grupa form pokrewnych: przymiotnik dolinowy jako określenie znamionujące złodzieja, wskazujące na jego specjalność - dolinowy buchaczl dolinowy andrus 'złodziej kieszonkowy' GzESTR, SMZKUR, nazwa złodzieja - doliniarz 'złodziej kieszonkowy' GzEsTR, ŻzUDZ, SzWESTR, SGWŁoŚ, SMZLUDWA, określenia czynności kradzieży, także w postaci frazeologizmów - dolinować 'kraść z kieszeni' SMzLUDWA, wyrulować z doliny 'wyciągnąć z kieszeni' SzWESTR, zmierzyć dolinę 'włożyć rękę do cudzej kieszeni' SMzLuDWA (niektóre z nich odnotowują XX-wieczne słowniki ogólne - przykładowo doliniarza jako słowo środowiskowe znajdziemy w SDOR, USJP, WSJP).

Kolejnym neologizmem semantycznym jest słowo pajęczyna 'bielizna', notowane w JzEsTR(B), GzEsTR, SMzKUR, SzWEsTr, SMZLUDWA (zob. Bąk, Kwiatkowska, 2009, s. 116), a od XX w. posiadające rozszerzony sens: 'kradzież bielizny ze strychu' SMZLUDWA (z tego samego okresu pochodzą synonimiczne frazeologizmy okurzyć pajęczynę 'okraść strych z bielizny' SMZLUDWA oraz omieść pajęczynę na wierzchołku 'ts.' SMZLUDWA). Zauważmy, że w źródłach objętych ekscerpcją pojawiają się także inne nazwy przedmiotów, obiektów kradzieży - pająk 'tłumok' GzESTR, 'koszula' JzESTR(B), GZESTR, SZWESTR, które uprawomocniają tezę, że znaczenie określenia pajęczyna jest motywowane skojarzeniem przedmiotów wykonanych z tkanin z siecią utkaną przez owada. To zresztą uzasadniałoby obecność derywatów nazywających złodzieja „zajmującego się pajęczyną” - pajęczeniarz 'złodziej bielizny' GzESTR, SzWESTR/ pajęczyniarz SGWŁoŚ/ pajęczarz 'złodziej bielizny ze strychu' SMzLUDWA. Historyczne i współczesne słowniki języka polskiego przy haśle pajęczyna nie notują znaczeń 'bielizna' czy 'koszula', co pozwala założyć, że określenie nie było i nie jest spopularyzowane w mowie pozaprzestępczej; podobnie przedstawia się sprawa, jeśli chodzi o słowniki socjolektalne. Natomiast trwanie nazwy $\mathrm{w}$ gwarze złodziejskiej $\mathrm{z}$ drugiej połowy XX w. poświadczają JZUŁASZ, STGPSTĘP i SAKAN.

Łatwe - wręcz oczywiste - jest ustalenie motywacji nazwy rogi 'wół', która ginie na przełomie XIX i XX w. (potwierdzają ją jeszcze: JzESTR(B), GZESTR, SZWESTR, a jako określenie dawniej używane w gwarze warszawskiej 
wymienia GWWIECZ): nazwa części ciała zwierzęcia stała się metonimicznym określeniem tego właśnie zwierzęcia. Dawne opracowania z zakresu socjolektów przestępczych przytaczają również szereg innych, pokrewnych nazw bydła rogatego: określenia krowy - rogala JzESTR(B), GzESTR, SzWESTR, rogula SMZKUR, SMZLUDWA, rogalina SZWESTR, ale też krowy i bydła w ogóle rogal JzEsTR(B), GzESTR, SZWEsTR, rogacz 'wół' SMZLUDWA.

Trudności $w$ ustaleniu proweniencji nie przynosi także nazwa szumowisko 'pałka', która - podobnie jak wcześniejsze określenie - zanika w mowie przestępców na przełomie XIX i XX w. Nadal notują ją JzESTR(B), GzEsTR, SzWESTR, ale w późniejszych opracowaniach już jej nie ma; nie przeszła ona również do polszczyzny potocznej. Określenie jest derywatem od znanego dawnemu językowi kryminalistów wyrazu szum 'las' JZESTR(B), GzESTR, SZWESTR/ 'las, gaj, sad, krzak' SMZKUR, SzWESTR i SMZLUDWA (jako miano historyczne, używane w gwarze warszawskiej podaje je też GWWIECZ) i z sensami tego właśnie słowa należy łączyć również znaczenie 'pałka', wszak chodzi o długi, gruby, drewniany pałąk, kij, czyli przedmiot wykonany z gałęzi drzew lub krzewów rosnących w lasach czy sadach.

Jeśli chodzi o określenia pieniędzy, których artykuł prasowy z $1778 \mathrm{r}$. wymienia aż cztery, to wszystkie one nie mają już poświadczenia w SMZLUDWA z 1822 r., brak ich także w historycznych i współczesnych słownikach ogólnych, co z kolei ujawnia, że żadne z nich nie przedostało się do innych odmian polszczyzny. Stosunkowo wczesny zanik niektórych wiąże się z tym, że zmieniła się rzeczywistość pozajęzykowa, przestawały istnieć desygnaty, do których określenia się odnosiły; na przykład: czerwone złote, $\mathrm{w}$ analizowanym materiale występujące pod nazwą opaleńce, wybijano do końca XVIII w., a ich odpowiedniki, czyli dukaty, funkcjonowały tylko czasowo, w trzech pierwszych dekadach XIX w. Co się natomiast dotyczy pochodzenia poszczególnych słów, to: leksem łakomce 'pieniądze' (notowany jeszcze w JzESTR(A), GzESTR, SZWESTR, a jako dawny w GWWIECZ) na gruncie języka przestępczego pojawił się jako neosemantyzm powstały $\mathrm{w}$ drodze przeniesienia znaczenia i jednoczesnej jego zmiany (odwrócenia - nazwa tego, kto jest łasy na pieniądze, stała się mianem tego, co jest przez niego pożądane), wszak łakomca to kiedyś 'człowiek chciwy jedzenia, picia, żarłok; chciwy zbieracz, skąpiec'; określenie rudnik 'moneta biała' (przytaczane nadal w JZESTR(B)， GZESTR, SzWESTR, homonimiczne do rudnik 'robotnik w kopalniach rudy, górnik' i 'kopalnia, cech, pieczara, szyba' SWIL, SW) wiąże się z nazwą materiału, z którego wykonywano monety, jest derywatem od ruda 'minerał, z którego wytwarza się metal'; nazwa opaleniec 'pieniądz: czerwony 
złoty' (notowana jeszcze w JZESTR(B), GzESTR, SzWESTR [tu jednak jako 'dukat']) jest mianem motywowanym kolorem - to neosemantyzm odnoszący się do pomarańczowoczerwonej monety, a więc barwą przypominającej metal poddany działaniu ognia - rozżarzony i/lub wystygnięty, ale nieobrobiony (por. opaleniec 'pogorzelec; który opalił sobie włosy, twarz' SL, SWIL, SW); natomiast określenie ruson 'moneta biała' (notowane w JZESTR(B), a w GZESTR, SZWESTR w sensie 'srebro'7), to najprawdopodobniej neologizm strukturalny utworzony od Rus 'Rusin, Rosjanin', a prawdopodobieństwo tej tezy podtrzymuje fakt, że nazwę tę podawali autorom XIX-wiecznych słowniczków informatorzy $\mathrm{z}$ obszarów znajdujących się $\mathrm{w}$ zaborze rosyjskim ${ }^{8}$.

Bardziej kłopotliwe jest wskazanie źródeł dwóch pozostałych określeń wymienionych w artykule z „Gazety Warszawskiej” z 1778 r. - sumeri filucha.

Co się dotyczy leksemu sumer 'chleb', notowanego w XIX w. i pierwszych dziesięcioleciach następnego stulecia: JzESTR(B), GZESTR, SMZKUR, JBFEL (tu w postaci somer), KPLJAW (jako zumer) (zob. Bąk, Kwiatkowska, 2009, s. 115), SZWESTR (też jako summer), SMZLUDWA (także jako sumyr), to wiele wskazuje na to, że ma ono związek z językiem wschodniosłowiańskim (rosyjskim lub ukraińskim). Określenie bowiem było również znane polszczyźnie kresowej (zob. Kurzowa, 1985, s. 90; Smułkowa, 1996, s. 249; Jakubowska, 1998, s. 262) i występowało w gwarze ochweśnickiej (Budziszewska, 1957, s. 93). Prawdopodobnie jest to pożyczka z ruszczyzny, wszak na gruncie rosyjskiego socjolektu przestępczego z przełomu XVIII i XIX w. znajdziemy słowo sumar' (сумарь) 'chleb' (Приёмышева, 2009, s. 14), które - jako sumar (сумар) i w znaczeniu 'czarny chleb' - poświadczone jest także w opracowaniach z początku XX w. (BMTRACH z 1908 r., SWIAJPOP z 1912 r., BM z 1923 r.) i późniejszych. Dokładnie rzecz ujmując, należy zaznaczyć, że ruszczyzna jest w tym przypadku tylko pośrednikiem, wszak źródło słowa leży w języku baszkirskim, gdzie sumar 'kluski', bądź tatarskim, w którym to samo znaczenie posiada słowo čumar (Karaś, 1952, s. 44; Reychman, 1965, s. 162; Дмитриев, 1931, s. 159-179). Jako wyraz złodziejski, wywodzący się z języka rosyjskiego sumer 'chleb' odnotowany został w SW; inne, późniejsze słowniki ogólne nie podają słowa jako leksemu środowiskowego czy potocznego, choć jako określenie używane w gwarze warszawskiej potwierdza je GWWIECZ, jako argotyzm wciąż należący do mowy

\footnotetext{
7 Sens 'srebro' być może dlatego, że w Królestwie Kongresowym do lat 40. XIX w. emitowano złoty polski i jego wielokrotność w srebrze; zob. Dylewski, 2011, s. 240.

8 Por. obecne w gwarze ochweśników z 1 poł. XIX w.: rusim/ rusun/ ruson 'złotówka'; Budziszewska, 1957, s. 90.
} 
przestępców przytacza SAKAN (zob. Jochym-Kuszlikowa, 2002, s. 104) i STGPSTĘP (tu w postaciach sumer, zumer, symer, szmer), a jako żywe $\mathrm{w}$ polskiej gwarze konspiracyjno-partyzanckiej $\mathrm{z}$ okresu drugiej wojny światowej podaje PGKPKAN.

Natomiast wyraz filucha 'chustka', którego funkcjonowanie w gwarach przestępczych zXIX w. i pierwszych dekad XX w. dowodzą notacje w JZESTR(A), GzESTR, KPLJAW, SMZKUR, SzWESTR (tu: 'chustka do nosa'), jest jak można przypuszczać - zniekształceniem fonetycznym znanego polszczyźnie od XV w. słowa pielucha 'chusta, zwykle płócienna, do obwijania niemowlęcia' SSTP, SXVI, SL, SWIL, SW ( $\leftarrow$ psł. *pelucha 'okrycie, pielucha, chusta' $\leftarrow$ pie. *pel- 'okrywać, osłaniać'; por. pol. pielesz, fr. peluche 'kłaczek, skrawek tkaniny') ((Boryś, 2005, s. 429; Brückner, 1927, s. 408; Bańkowski, 2000, s. 552-553). Za taką proweniencją przemawia fakt, że w XIX- i XX-wiecznym socjolekcie środowisk przestępczych znajdziemy słowa pieluchal pieluchy, które nie tylko odnoszą się do sensu 'chustka', ale są określeniami przedmiotów wykonanych z tkanin w ogóle: 'spodnie' SGWWIECZ, STGPSTĘP, 'chustka' JZUŁASZ, STGPSTĘP, 'koszula' STGPSTĘP (zob. Bąk, Kwiatkowska, 2009, s. 116), 'sweter' STGPSTĘP, 'bluzka' STGPSTĘP, 'chustka do nosa' STGPSTĘP. Wypada przy tym wspomnieć o wariantywnych formach (zniekształceniach) spotykanych $\mathrm{w}$ historycznych opracowaniach poświęconych socjolektom środowisk przestępczych, poświadczających trwanie słowa filucha 'chustka' w XIXi XX-wiecznym socjolekcie; i tak: w JZESTR(A), GzESTR, SzWESTR, SMZLUDWA spotkamy postać filicha 'chustka, chusteczka do nosa', a w JBFEL i KPLJAW zetkniemy się z formą felicha 'jw.'․ Jako określenie dawniej używane w gwarze warszawskiej leksem filucha wymieniają GWWIECZ i SGWWIECZ, z kolei jego obecność w mowie przestępców z drugiej połowy XX w. potwierdzają notacje w JZUŁASZ (tu postać filicha jako wymarła), STGPSTĘP (tutaj jako filichal filuchal filicka 'chustka, chusteczka do nosa').

\section{Podsumowanie}

Spośród osiemnastu słów wymienionych w notatce prasowej z $1778 \mathrm{r}$. najkrótszy żywot miało sześć, nie notuje ich już opracowanie Ludwikowskiego i Walczaka z 1922 r.: łakomce 'pieniądze', opaleniec 'pieniądz: czerwony złoty', rudnik 'moneta biała', ruson 'moneta biała', sięgawka 'ręka', zająć 'uderzyć' i zmieść 'ukraść' (ostanie poświadczenie występuje w SzWESTR). Mało tego,

\footnotetext{
${ }^{9}$ Formę filicha 'chustka' jako kresowizm notuje też praca: Kurzowa, 1985, s. 435.
} 
dwa z tych leksemów na przełomie XIX i XX w. miały już zmodyfikowane sensy: określenie opaleniec przestało się odnosić do czerwonego złotego, a stanowiło nazwę dukata w ogóle (por. JZESTR(B) i SZWESTR), z kolei słowo ruson przestało być wyłącznie nazwą białej monety, a odnosiło się do srebra (por. JZESTR(B) i SzWESTR). Część leksemów, które przetrwały do drugiej połowy XX w., nie należy już tylko do socjolektu przestępczego $\mathrm{w}$ znaczeniach tożsamych $\mathrm{z}$ sensami obecnymi w XVIII-wiecznej mowie półświatka końcem XIX w. niektóre słowa zaczęły wchodzić do polszczyzny potocznej, a współcześnie traktuje się je nawet jako argotyzmy należące do innych socjolektów (buchnąć 'ukraść', makówka 'głowa', dolina 'kieszeń') (zob.: Kołodziejek, 2009, s. 225-232; Zgółkowa, 1994, s. 41-47). I jeszcze jedna istotna uwaga - wszystkie jednostki wymienione w artykule z „Gazety Warszawskiej” w XIX w. miały charakter ogólnopolski (jak wynika z notacji występujących w opracowaniach, znajomość tych słów potwierdzali informatorzy pochodzący m.in. ze Lwowa, z Warszawy czy z Krakowa).

W zakończeniu wypada także podkreślić, że chociaż słownictwo omówione $\mathrm{w}$ niniejszym artykule wyekscerpowano tylko $\mathrm{z}$ jednego tekstu XVIII-wiecznej prasy, to $\mathrm{w}$ zasadzie ma ono znacznie dłuższą historię (niewykluczone, że tak długą, jak długa jest historia fachu złodziejskiego czy instytucji więzienia w Polsce, acz nieudokumentowaną [szerzej m.in. w: Kracik, Rożek, 1986]). Część przedstawionych leksemów znana była polszczyźnie w XVI i XVII w., co potwierdzają między innymi dokumenty archiwalne i literatura z tamtego okresu (obecność słownictwa złodziejskiego w tekstach literackich świadczy jednak o tym, że już wtedy elementy mowy przestępczej przenikały do języka ogólnego) ${ }^{10}$. Stąd też wiadomo, że staropolscy złoczyńcy posługiwali się między innymi określeniami: buchnąć 'ukraść', buchacz 'złodziej', sięgawka 'kieszeń' (sens inny niż przywołany w artykule). Wydaje się przy tym, że konieczna jest bliższa obserwacja materiału językowego zamieszczonego $\mathrm{w}$ tych archaicznych źródłach - z pewnością

\footnotetext{
${ }^{10}$ I tak na przykład, w Liber maleficorum z 1574 r. pisarz sądowy na marginesie zeznań nijakiego Jana z Gołańca odnotował następujące słowa tzw. „waltarskiej mowy”: oman - pieniądze, wątrobnica - kaleta, postrzelczył - ujrzał, koło - talary, zapołoniec - czerwony złoty, twarogowe łyżki - śrzebne łyżki, szczypawnik - wacek, zakęsik - nóż, co nim rzezą, pukawki - rusznice, węzeł - kłódka, bez - piwo, kał- grosz, machcik - złodziej, rogowacz - bicz, skruch - kat. Cyt. za: Maisel, 1956, s. 74-75 (autor opierał się na dokumencie archiwalnym Acta criminalia Posnaniensia nr 475, f. 15v (Wojewódzkie Archiwum Państwowe w Poznaniu). Wspomniane tutaj oraz inne słowa złodziejskie pojawiające się w staro- i średniopolskich dokumentach wymienia też opracowanie: Kamler, 2010 (m.in. s. 70).
} 
analizy takie pogłębią wiedzę na temat historii słownictwa polskiego socjolektu środowisk przestępczych.

Autor zadaje sobie sprawę z tego, że przedstawione analizy w niektórych miejscach mogą się okazać mało przekonujące dla czytelnika lub mogą wymagać uzupełnień, wierzy więc, że jeśli artykuł sprowokuje odbiorców do dyskusji, to tylko z korzyścią dla samej wiedzy o historycznym socjolekcie przestępczym - dokładniejszego jego poznania i opisu.

\section{BIBLIOGRAFIA}

a) Źródła (wraz z wykazem skrótów zastosowanych w tekście)

Bм - [s.n.] (1923). Блатная музыка. Словарь жаргона преступников. Издание управления уголовного розыска республики. Москва: Народный Комиссариат Внутренних Дел.

ВмТRAсH - Трахтенберг, В.Ф. (1908). Трахтенберг Блатная музыка („жаргон” тюрьмы). Санкт-Петербург: Типография А.Г. Розена.

GWWIECz - Wieczorkiewicz, B. (1968). Gwara warszawska dawniej $i$ dziś. Warszawa: Państwowy Instytut Wydawniczy.

GzEsTR - Estreicher, K. (1867). Gwara złoczyńców. Warszawa: [s.n.].

JBFEL - Felsztyński, H. (1861-1863). Wiadomość o języku bosańskim w Galicyi, do uzupełnień słownika Lindego (rękopisy); cyt. za: Pluta, F. (2002). Charakterystyka lwowskiego języka „bosańskiego”. W: S. Gajda, K. Rymut, U. Żydek-Bednarczuk (Red.), Język w przestrzeni społecznej (ss. 167-174). Opole: Instytut Filologii Polskiej UP - Opolskie Towarzystwo Przyjaciół Nauk.

JzEstR(A) - Estreicher, K. (1859). Język złoczyńców. Rozmaitości. Pismo dodatkowe do Gazety Lwowskiej, 12, 89-92.

JzEstR(B) - Estreicher, K. (1859). Język złoczyńców. Rozmaitości. Pismo dodatkowe do Gazety Lwowskiej, 13, 97-100.

JzEstR(c) - Estreicher, K. (1859). Język złoczyńców. Rozmaitości. Pismo dodatkowe do Gazety Lwowskiej, 14, 105-110.

KPLJAW - Jaworskij J. (1901). „Kumać po lembersku”. Przyczynek do słownika lwowskiej gwary złodziejskiej. Lud, 7, 276-281.

PGKPKAN - Kania, S. (1986). Polska gwara konspiracyjno-partyzancka. 1939-1945. Warszawa Poznań: Państwowe Wydawnictwo Naukowe.

SARGKAN - Kania, S. (1995). Słownik argotyzmów. Warszawa: Państwowe Wydawnictwo "Wiedza Powszechna”.

SDoR - Doroszewski, W. (red.) (1958-1969). Słownik języka polskiego. T. 1-11. Warszawa: Państwowe Wydawnictwo „Wiedza Powszechna” - Państwowe Wydawnictwo Naukowe.

SGUZG - Zgółkowa, H., Czarnecka, K. (1991). Słownik gwary uczniowskiej. Poznań: Kantor Wydawniczy SAWW.

SGWŁoś - Łoś, J. (1913). Słowniczek gwary więziennej. Język Polski, I, 10, 296-299.

SGWWIECZ - Wieczorkiewicz, B. (1966). Słownik gwary warszawskiej XIX wieku. Warszawa: PWN. 
SL - S.B. Linde (1807-1814). Słownik języka polskiego. T. 1-6. Warszawa: Drukarnia XX. Pijarów.

SMzKuR - Kurka, A. (1899). Słownik mowy złodziejskiej. Lwów: [s.n.].

SPLP - Lubaś, W. (red.) (2001). Słownik polskich leksemów potocznych. T. 1-10. Kraków: Instytut Języka Polskiego PAN - Wydawnictwo Lexis.

SPP - Czeszewski, M. (2006). Słownik polszczyzny potocznej. Warszawa: Wydawnictwo Naukowe PWN.

SSTP - Urbańczyk, S. (1953-2002). Słownik staropolski. t. 1-11. Kraków: Instytut Języka Polskiego PAN.

STĘPSTGP - Stępniak, K., Podgórzec, Z. (1993). Słownik tajemnych gwar przestępczych. Londyn: Wydawnictwo Puls.

SW - Karłowicz, J., Kryński, A.A., Niedźwiedzki, W. (1900-1927). Słownik języka polskiego. T. 1-8. Warszawa: nakładem prenumeratorów w drukarni E. Lubowskiego i S-ki, nakładem prenumeratorów i Kasy im. Mianowskiego w drukarni „Gazety Handlowej”.

SWIAJPOP - Попов, В.Ф. (1912). Словарь воровского и арестантского языка. Киев: т-во „Печатня С.П. Яковлева”.

SWIL - Zdanowicz, A. i in. (red.) (1861). Słownik języka polskiego. Wilno: Wydany staraniem i kosztem Maurycego Orgelbranda.

SXVI - Mayenowa, M.R., Pepłowski, F. i in. (1966-), Słownik polszczyzny XVI wieku. Wrocław - Warszawa: Ossolineum - Instytut Badań Literackich PAN.

SXVII/XVIII - Gruszczyński, W. (red.) (1996-). Słownik języka polskiego XVII i 1. połowy XVIII wieku. Kraków: Instytut Języka Polskiego PAN.

SzWEstR - Estreicher, K. (1903). Szwargot więzienny. Warszawa: Księgarnia D.E. Friedlein.

UsJP - Dubisz, S. (red.) (2003). Uniwersalny słownik języka polskiego. T. 1-4. Warszawa: Wydawnictwo Naukowe PWN.

WsJP - Żmigrodzki, P. (red.) (2007-). Wielki słownik języka polskiego PAN. Kraków: Instytut Języka Polskiego PAN.

ŻMPLuDWA - Ludwikowski, W., Walczak, H. (1922). Żargon mowy przestępców. „Błatna muzyka”. Ogólny zbiór słów gwary złodziejskiej. Warszawa: [s.l.].

ŻzUDz - Udziela, S. (1892). Żargon złodziejski we Lwowie (rękopis); cyt. za: Rak, M. (2016). Kilka uwag o socjolekcie przestępczym polszczyzny przedwojennego Lwowa. Socjolingwistyka, 30, 133-145.

\section{b) Opracowania}

Appel, K. (1908). Język i społeczeństwo. Lingwistyka i socjologia. Warszawa: Księgarnia Gebethnera i Wolffa.

Bańkowski, A. (2000). Etymologiczny słownik języka polskiego. Tom II: L-P. Warszawa: Wydawnictwo PWN.

Bąk, M., Kwiatkowska, T. (2009). System wartości $i$ oceny na materiale odzieży $i$ jedzenia $w$ rosyjskim $i$ polskim żargonie przestęczym. W: А. Зых, М. НадельЧервиньска (Red.), Лексика подстандарта. T. 2. Современные жаргоны и их описание (ss. 112-121). Katowice: Wydawnictwo Uniwersytetu Śląskiego.

Boryś, W. (2005). Słownik etymologiczny języka polskiego. Kraków: Wydawnictwo Literackie.

Brückner, A. (1927). Słownik etymologiczny języka polskiego. Kraków: Krakowska Spółka Wydawnicza.

Budziszewska, W. (1957). Żargon ochweśnicki. Łódź - Wrocław: Łódzkie Towarzystwo Naukowe - Zakład im. Ossolińskich. 
Buttler, D. (1991). Przenośnie polszczyzny potocznej. Prace Filologiczne, XXXV, 39-46.

Хобзей, Н., Сімович, К., Ястремська, Т., Дидик-Меуш, Г. (2012). Лексикон львівський: поважно і на жарт. Львів: Інститут українознавства ім. І.Крип'якевича НАН України.

Długosz-Kurczabowa, K. (2005). Słownik etymologiczny języka polskiego. Warszawa: Wydawnictwo PWN.

Дмитриев, Н.К. (1931). Турецкие элементы русского арго. Язык и литература, 7, 159-179.

Dylewski, A. (2011). Historia pieniądza na ziemiach polskich. Warszawa: Carta Blanca. Grupa Wydawnicza PWN.

Grabias, S. (1974). Funkcyjna klasyfikacja socjalnych wariantów języka. Język Polski, LIV, 1, 22-31.

Grabias, S. (1994). Język w zachowaniach społecznych. Lublin: Wydawnictwo Uniwersytetu Marii Curie-Skłodowskiej.

Grabias, S. (2019). Język w zachowaniach społecznych. Podstawy socjolingwistyki i logopedii. Lublin: Wydawnictwo Uniwersytetu Marii Curie-Skłodowskiej.

Jaczewski, E. (1938-1939). Gwara miejska Warszawy. Poradnik Językowy, 9-10, 173-180.

Jakubowska, U. (1998). Mit lwowskiego batiara. Warszawa: Instytut Badań Literackich, Polska Akademia Nauk.

Jochym-Kuszlikowa, L. (2002). Argotyzmy pochodzenia rosyjskiego we współczesnym języku polskim. Annales Academiae Paedagogicae Cracoviensis. Folia 6. Studia Linguistica, I, 97-110.

Kamler, M. (2010). Złoczyńcy. Przestępczość w drugiej połowie XVI i w pierwszej połowie XVII wieku (w świetle ksiąg sądowych miejskich). Warszawa: Wydawnictwo Neriton Instytut Historii PAN.

Karaś, M. (1952). Jeszcze o ciuchach. Język Polski, XXXII, 1, 42-44.

Karwatowska, M., Jarosz, B. (2011). O języku zawodowym policjantów. Acta Humana, 2, 15-26.

Kołodziejek, E. (2009). „Rozkminianie” gwar tajemnych. W: A. Dąbrowska (Red.), Język a kultura. Tom 21: Tabu w języku i kulturze (ss. 225-232). Wrocław: Wydawnictwo Uniwersytetu Wrocławskiego.

Kracik, J., Rożek, M. (1986). Hultaje, złoczyńcy, wszetecznice w dawnym Krakowie. O marginesie społecznym XVI-XVIII w.. Kraków - Wrocław: Wydawnictwo Literackie.

Królikowska, S. (1975). O współczesnym słownictwie przestępców. Zeszyty Naukowe Uniwersytetu Eódzkiego. Nauki Humanistyczno-Społeczne, 110, 55-77.

Kurzowa, Z. (1985). Polszczyzna Lwowa i kresów południowo-wschodnich do 1939 roku. Warszawa - Kraków: Państwowe Wydawnictwo Naukowe.

Maisel, W. (1956). Poznański słowniczek żargonu złodziejskiego z XVI wieku. Język Polski, $X X X V I, 1,74-75$.

Małocha, A. (1994). Żydowskie zapożyczenia leksykalne $w$ socjolekcie przestępczym. W: J. Anusiewicz, B. Siciński (Red.), Język a kultura. Tom 10: Język subkultur (ss. 135-170). Wrocław: Wiedza o Kulturze.

Michel, F. (1856). Études de philologie comparée sur l'argot et sur les idiomes analogues parlés en Europe et en Asie. Paris: Paris Firmin Didot frères, fils et cle.

Milewski, S. (1971). Gwara przestępcza i jej przenikanie do języka ogólnego. Poradnik Językowy, 2, 91-101.

Pacuła, J. (2019a). Kilka zapomnianych ekspresywnych nazw strażników więziennych. (Nie)oczywista proweniencja. Świat i Słowo, 33, 245-258.

Pacuła, J. (2019b). O kilku judaikach w polskim socjolekcie przestępczym. Linguistica Copernicana, XVI, 363-379. 
Приёмышева, М.Н. (2009). Тайные и условные языки в России XIX в. Ч. 1. Санкт-Петербург: Нестор-История.

Reychman, J. (1965). Zapożyczenia tureckie w polskiej gwarze złodziejskiej. Język Polski, XLV, 3, 143-163.

Saint-Hilaire, E., Raban F. (1929). Mémoires d'un forçat, ou Vidocq dévoilé. Tome Quatrieme. Paris: Langlois.

Smułkowa, E. (1996). Uwagi o języku starszego pokolenia inteligencji lwowskiej A.D. 1989/1990. W: J. Rieger (Red.), Język polski dawnych Kresów Wschodnich. Studia i materiały. Tom 1 (ss. 223-255). Warszawa: Semper.

Stępniak, K. (1972). Z historii polskiej gwary złodziejskiej. Prace Filologiczne, XXIII, 263-279.

Ułaszyn, H. (1913). Przyczynki leksykalne 1. Gwara złodziejska z około roku 1840. Materyały i Prace Komisyi Językowej Akademii Umiejętności w Krakowie, VI, 271-285.

Ułaszyn, H. (1951). Język złodziejski, Łódź: Łódzkie Towarzystwo Naukowe.

Witkowski, W. (1992). Elementy żargonu złodziejskiego we współczesnym języku ogólnopolskim. W: W. Boryś, W. Sędzik (Red.), Studia z dialektologii polskiej i słowiańskiej (ss. 271-173). Warszawa: Instytut Słowianoznawstwa PAN.

Zacone P., Clémens (1870). Dictionnaire (d'argot) - Bagnes de France - Avec la traduction en français. Paris: Victor Bunel.

Zgółkowa, H. (1994). Grypsera w szkole. Przenikanie słownictwa środowisk przestępczych do żargonu uczniowskiego. W: H. Zgółkowa (Red.), Słowa służebne. Prace ofiarowane Profesor Monice Gruchmanowej na 70-lecie Jej urodzin (ss. 41-47). Poznań: Wydawnictwo Naukowe Uniwersytetu Adama Mickiewicza. 